\title{
Contributions by a Novel Edge Effect to the Permselectivity of an Electrosynthesized Polymer for Microbiosensor Applications
}

\author{
Sharon A. Rothwell, ${ }^{\dagger}$ Michael E. Kinsella, ${ }^{\dagger}$ Zainiharyati M. Zain, ${ }^{t, \neq}$ Pier A. Serra, \\ Gaia Rocchitta, ${ }^{t, \S}$ John P. Lowry," and Robert D. O’Neill*,t
}

\begin{abstract}
UCD School of Chemistry and Chemical Biology, University College Dublin, Belfield, Dublin 4, Ireland, Pusat Pengajian Sains Kimia, Universiti Sains Malaysia, Pulau Pinang, Malaysia, Department of Neuroscience, Medical School, University of Sassari, Viale S. Pietro 43/b, 07100 Sassari, Italy, and Department of Chemistry, National University of Ireland, Maynooth, Co. Kildare, Ireland
\end{abstract}

Pt electrodes of different sizes $\left(2 \times 10^{-5}-2 \times 10^{-2} \mathrm{~cm}^{2}\right)$ and geometries (disks and cylinders) were coated with the ultrathin non-conducting form of poly(o-phenylenediamine), PPD, using amperometric electrosynthesis. Analysis of the ascorbic acid (AA) and $\mathrm{H}_{2} \mathrm{O}_{2}$ apparent permeabilities for these $\mathrm{Pt} / \mathrm{PPD}$ sensors revealed that the PPD deposited near the electrode insulation (Teflon or glass edge) was not as effective as the bulk surface PPD for blocking AA access to the Pt substrate. This discovery impacts on the design of implantable biosensors where electrodeposited polymers, such as PPD, are commonly used as the permselective barrier to block electroactive interference by reducing agents present in the target medium. The undesirable "edge effect" was particularly marked for small disk electrodes which have a high edge density (ratio of PPDinsulation edge length to electrode area), but was essentially absent for cylinder electrodes with a length of $>0.2 \mathrm{~mm}$. Sample biosensors, with a configuration based on these findings $(25 \mu \mathrm{m}$ diameter $\mathrm{Pt}$ fiber cylinders) and designed for brain neurotransmitter L-glutamate, behaved well in vitro in terms of Glu sensitivity and AA blocking.

The design of biosensors for implantation in functioning biological tissues is an important area of research with significant socioeconomic impact. ${ }^{1-4}$ Depending on the target analyte, different signal transduction pathways have been exploited in the design of enzyme-based biosensors, including direct oxidation of

\footnotetext{
* To whom correspondence should be addressed. E-mail: robert.oneill@ucd.ie. Fax: +353-1-7161178. Phone: +353-1-7162314.

$\dagger$ University College Dublin.

* Universiti Sains Malaysia.

$\S$ University of Sassari.

"National University of Ireland, Maynooth

(1) Wang, J. Chem. Rev. 2008, 108, 814-825.

(2) O’Neill, R. D.; Lowry, J. P.; Rocchitta, G.; McMahon, C. P.; Serra, P. A. Trends Anal. Chem. 2008, 27, 78-88.

(3) Grieshaber, D.; MacKenzie, R.; Voros, J.; Reimhult, E. Sensors 2008, 8, 1400-1458.

(4) Privett, B. J.; Shin, J. H.; Schoenfisch, M. H. Anal. Chem. 2008, 80, 44994517.
}

reduced oxidases, ${ }^{5-7}$ dehydrogenase chemistries, ${ }^{8-10}$ redox mediators, ${ }^{11-13}$ and spectrophotometric approaches. ${ }^{14-16}$ However, "first generation" electrochemical biosensors, based on reactions $1-3$, remain the most common design for many applications. ${ }^{1,2,17-19}$ The majority of these are oxidase-based devices designed to operate in amperometric mode, detecting $\mathrm{H}_{2} \mathrm{O}_{2}$ generated by the reaction of the co-substrate (dioxygen) with the reduced form of the enzyme.

$$
\begin{gathered}
\text { Substrate }+\mathrm{Ox} / \mathrm{FAD} \rightarrow \text { Products }+\mathrm{Ox} / \mathrm{FADH}_{2} \\
\mathrm{Ox} / \mathrm{FADH}_{2}+\mathrm{O}_{2} \rightarrow \mathrm{Ox} / \mathrm{FAD}+\mathrm{H}_{2} \mathrm{O}_{2} \\
\mathrm{H}_{2} \mathrm{O}_{2} \rightarrow \mathrm{O}_{2}+2 \mathrm{H}^{+}+2 \mathrm{e}^{-}
\end{gathered}
$$

First-generation biosensors in general, and especially those designed for tissue implantation, ${ }^{20-24}$ must be capable of effective rejection of electroactive interference by endogenous reducing agents in the target medium because these devices are normally operated at a high applied overpotential for efficient $\mathrm{H}_{2} \mathrm{O}_{2}$

(5) Bernhardt, P. V. Aust. J. Chem. 2006, 59, 233-256.

(6) Xu, Z.; Chen, X.; Dong, S. J. Trends Anal. Chem. 2006, 25, 899-908.

(7) Murphy, L. Curr. Opin. Chem. Biol. 2006, 10, 177-184.

(8) Stoica, L.; Ludwig, R.; Haltrich, D.; Gorton, L. Anal. Chem. 2006, 78, 393-398.

(9) Tang, X. J.; Xie, B.; Larsson, P. O.; Danielsson, B.; Khayyami, M.; Johansson, G. Anal. Chim. Acta 1998, 374, 185-190.

(10) Cosford, R. J. O.; Kuhr, W. G. Anal. Chem. 1996, 68, 2164-2169.

(11) Kuwabata, S. Chem. Lett. 2008, 37, 230-235.

(12) Chakraborty, S.; Raj, C. R. Electrochem. Commun. 2007, 9, 1323-1330.

(13) Lin, Y. Q.; Liu, K.; Yu, P.; Xiang, L.; Li, X. C.; Mao, L. Q. Anal. Chem. 2007, 79, 9577-9583.

(14) Wei, H.; Wang, E. Anal. Chem. 2008, 80, 2250-2254.

(15) Doong, R. A.; Shih, H. M. Biosens. Bioelectron. 2006, 22, 185-191.

(16) Davis, F.; Higson, S. P. J. Biosens. Bioelectron. 2005, 21, 1-20.

(17) Pernot, P.; Mothet, J. P.; Schuvailo, O.; Soldatkin, A.; Pollegioni, L.; Pilone, M.; Adeline, M. T.; Cespuglio, R.; Marinesco, S. Anal. Chem. 2008, 80, 1589-1597.

(18) Foxx, D.; Kalu, E. E. Electrochem. Commun. 2007, 9, 584-590.

(19) Maalouf, R.; Chebib, H.; Saikali, Y.; Vittori, O.; Sigaud, M.; Garrelie, F.; Donnet, C.; Jaffirezic-Renault, N. Talanta 2007, 72, 310-4.

(20) Khan, A. S.; Michael, A. C. Trends Anal. Chem. 2003, 22, 503-508.

(21) Wilson, G. S.; Gifford, R. Biosens. Bioelectron. 2005, 20, 2388-2403.

(22) Wilson, G. S.; Hu, Y. B. Chem. Rev. 2000, 100, 2693-2704.

(23) O’Neill, R. D.; Lowry, J. P.; Mas, M. Crit. Rev. Neurobiol. 1998, 12, 69127.

(24) Pantano, P.; Kuhr, W. G. Electroanalysis 1995, 7, 405-16. 
detection (reaction 3). Thus, the analyte specificity of enzymebased amperometric biosensors can be seriously undermined when the interference species is present in high concentration, which is the case for ascorbic acid (AA), a ubiquitous reducing agent in biological fluids. ${ }^{25}$ This is particularly true when the target molecule is present at low concentrations, such as when monitoring the key neurotransmitters, glutamate ${ }^{26,27}$ and acetylcholine..$^{28,29}$ Even when significantly lower applied overpotentials can be used for direct $\mathrm{H}_{2} \mathrm{O}_{2}$ oxidation, ${ }^{30,31} \mathrm{AA}$ interference can persist because of its very low redox potential, ${ }^{32,33}$ and the use of redox-mediated HRP-based biosensors may suffer from indirect AA interference because HRP has been reported to catalyze the reaction between AA and $\mathrm{H}_{2} \mathrm{O}_{2} \cdot{ }^{13}$ The alternative strategy of $\mathrm{H}_{2} \mathrm{O}_{2}$ electroreduction $^{34-36}$ is also prone to interference, in this case by reduction of molecular oxygen in the target medium. ${ }^{37}$ Therefore, there is a real need for improvements in biosensor selectivity for biological applications, including real-time brain monitoring during behavior. ${ }^{2,23,29,38,39}$

We recently reported preliminary data on the effects of electrode size for implantable model biosensors incorporating a globular protein (GP) entrapped in a poly-o-phenylenediamine (PPD) interference-rejecting layer electrosynthesized onto $125 \mu \mathrm{m}$ diameter Pt cylinders $\left(\mathrm{Pt}_{\mathrm{C}}\right)$ and disks $\left(\mathrm{Pt}_{\mathrm{D}}\right) .^{40} \mathrm{The} \mathrm{Pt}_{\mathrm{D}} / \mathrm{PPD}-\mathrm{GP}$ electrodes showed a 10-fold poorer selectivity compared with the corresponding $\mathrm{Pt}_{\mathrm{c}} / \mathrm{PPD}-\mathrm{GP}$ design. Although that study raised the important issue of the influence of sensor size/ geometry on the properties of surface-deposited permselective polymers, it failed to elucidate the underlying cause of this phenomenon. In the present work, we extend the range of electrode size of PPD-coated sensors, and simplify the design by omitting the GP to focus on the Pt/PPD properties. A novel analysis of permeability parameters for a wide range of $\mathrm{Pt}$ / PPD sensors revealed an "edge effect" as the source of variability in the polymer permselectivity, findings that have important implications for the choice of the size and geometry of implantable biosensors.

(25) Li, Y.; Schellhorn, H. E. J. Nutr. 2007, 137, 2171-2184.

(26) Hascup, K. N.; Hascup, E. R.; Pomerleau, F.; Huettl, P.; Gerhardt, G. A. J. Pharmacol. Exp. Ther. 2008, 324, 725-731.

(27) Morales-Villagran, A.; Medina-Ceja, L.; Lopez-Perez, S. J. J. Neurosci. Meth. 2008, 168, 48-53.

(28) Du, D.; Ding, J. W.; Cai, J.; Zhang, A. D. J. Electroanal. Chem. 2007, $605,53-60$.

(29) Dale, N.; Hatz, S.; Tian, F. M.; Llaudet, E. Trends Biotechnol. 2005, 23, $420-428$.

(30) Lee, C. H.; Wang, S. C.; Yuan, C. J.; Wen, M. F.; Chang, K. S. Biosens. Bioelectron. 2007, 22, 877-884.

(31) Rahman, M. A.; Kwon, N. H.; Won, M. S.; Choe, E. S.; Shim, Y. S. Anal. Chem. 2005, 77, 4854-4860.

(32) Kulys, J.; Drungiliene, A. Electroanalysis 1991, 3, 209-214.

(33) Perone, S. P.; Kretlow, W. J. Anal. Chem. 1966, 38, 1760-1763.

(34) Wang, J.; Liu, J.; Chen, L.; Lu, F. Anal. Chem. 1994, 66, 3600-3603.

(35) Wang, J.; Lu, F.; Angnes, L.; Liu, J.; Sakslund, H.; Chen, Q.; Pedrero, M.; Chen, L.; Hammerich, O. Anal. Chim. Acta 1995, 305, 3-7.

(36) Rahman, M. A.; Won, M. S.; Shim, Y. B. Electroanalysis 2007, 19, 631637.

(37) Tatsuma, T.; Oyama, N. Anal. Chem. 1996, 68, 1612-1615.

(38) Wilson, G. S.; Ammam, M. FEBS J. 2007, 274, 5452-5461.

(39) Burmeister, J. J.; Gerhardt, G. A. Trends Anal. Chem. 2003, 22, 498502.

(40) McMahon, C. P.; Killoran, S. J.; Kirwan, S. M.; O’Neill, R. D. J. Chem. Soc., Chem. Commun. 2004, 2128-2130.

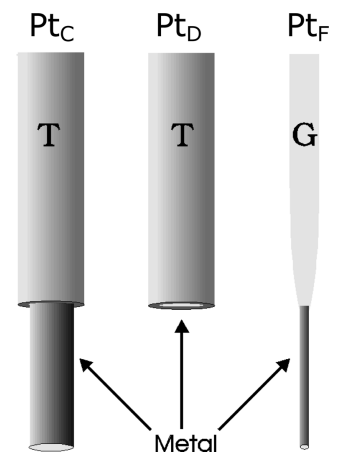

Figure 1. Schematic representation of the tips of the three main designs of working electrodes investigated here: $\mathrm{Pt}_{\mathrm{C}}$ (Teflon-coated cylinder: 50 or $125 \mu \mathrm{m}$ diameter, with a length of $1 \mathrm{~mm}$ in both cases; left); $\mathrm{Pt}_{\mathrm{D}}$ (Teflon-coated disk: 50 or $125 \mu \mathrm{m}$ diameter; center); and $\mathrm{Pt}_{\mathrm{F}}$ (glass-supported $\mathrm{Pt}$ fiber: $25 \mu \mathrm{m}$ diameter, with a length ranging from 0.1 to $2.0 \mathrm{~mm}$; right). $\mathrm{T}$ is Teflon and $\mathrm{G}$ is glass.

\section{EXPERIMENTAL SECTION}

Chemicals and Solutions. The monomer $o$-phenylenediamine (oPD) was obtained from Sigma, as were the two calibration analytes: ascorbic acid (AA); and $\mathrm{H}_{2} \mathrm{O}_{2}(30 \% \mathrm{w} / \mathrm{w}$ aqueous solution). All chemicals were used as supplied, although the exact $\mathrm{H}_{2} \mathrm{O}_{2}$ concentration was determined by titration against an oxalate-standardized permanganate solution. Calibrations were carried out in vitro in phosphate-buffered saline (PBS, $\mathrm{pH}$ 7.4) that consisted of $\mathrm{NaCl}$ (Sigma, $150 \mathrm{mM}$ ), $\mathrm{NaH}_{2} \mathrm{PO}_{4}$ (Fluka, $40 \mathrm{mM}$ ) and $\mathrm{NaOH}$ (Fluka, $40 \mathrm{mM}$ ). Solutions of oPD monomer $(300 \mathrm{mM})$ were made up in PBS. Stock solutions of $10 \mathrm{mM} \mathrm{H}_{2} \mathrm{O}_{2}$ and $100 \mathrm{mM} \mathrm{AA}$ were prepared in doubly distilled water and $0.01 \mathrm{M} \mathrm{HCl}$ respectively.

Working Electrode Preparation. Pt-Ir cylinders $\left(\mathrm{Pt}_{\mathrm{C}}\right)$ of 1 mm length were prepared by cutting sections of 50 or $125 \mu \mathrm{m}$ diameter Teflon-coated wire (90\% Pt, 10\% Ir from Advent Research Materials, Eynsham, England) as described previously. ${ }^{41-44} \mathrm{Pt}-\mathrm{Ir}$ disks $\left(\mathrm{Pt}_{\mathrm{D}}\right)$ were fabricated by cutting the Teflon-coated wire transversely, using a single rolling action of a new sharp scalpel blade, to produce $50 \mu \mathrm{m}$ and $125 \mu \mathrm{m}$ diameter disks (see Figure 1). The Pt fiber $\left(\mathrm{Pt}_{\mathrm{F}}\right)$ electrodes were prepared from $25 \mu \mathrm{m}$ diameter bare $\mathrm{Pt}$ wire (Goodfellow Cambridge Ltd., purity 99.9\%, hard temper) as follows. A glass capillary (diameter $1 \mathrm{~mm}$, Hawksley Ltd.) was pulled using a Kopf Vertical Pipette puller (David Kopf Instruments) to a narrow tip. An approximate $5 \mathrm{~cm}$ length of Teflon-insulated silver wire (Advent Research Materials Ltd.) was stripped of about $2 \mathrm{~mm}$ of its insulation at both ends. A $2 \mathrm{~cm}$ length of the fiber was attached to one end of the wire using silver conductive paint (Radionics Ltd.), allowed to dry, and then inserted, fiber end first, into the capillary tube so that the Pt protruded from the tip of the capillary. The other end of the silver wire was soldered into a gold clip. The fiber was sealed into the capillary by quickly rotating the tip of the capillary in

(41) Kirwan, S. M.; Rocchitta, G.; McMahon, C. P.; Craig, J. D.; Killoran, S. J.; O’Brien, K. B.; Serra, P. A.; Lowry, J. P.; O’Neill, R. D. Sensors 2007, 7, 420-437.

(42) McMahon, C. P.; Rocchitta, G.; Kirwan, S. M.; Killoran, S. J.; Serra, P. A.; Lowry, J. P.; O’Neill, R. D. Biosens. Bioelectron. 2007, 22, 1466-1473.

(43) McMahon, C. P.; Rocchitta, G.; Serra, P. A.; Kirwan, S. M.; Lowry, J. P.; O'Neill, R. D. Anal. Chem. 2006, 78, 2352-2359.

(44) McMahon, C. P.; Killoran, S. J.; O’Neill, R. D. J. Electroanal. Chem. 2005, 580, 193-202. 
a small flame for a few seconds so that the glass melted around the fiber, sealing the capillary-fiber junction. The opposite end of the glass capillary, with the silver wire protruding, was sealed using an epoxy resin (Araldite, Bostik) and allowed to dry for $24 \mathrm{~h}$ at room temperature. The protruding tip of the fiber was then cut to the desired length $(0.1-2.0 \mathrm{~mm})$.

Stock $300 \mathrm{mM}$ solutions of oPD monomer were used in the electro-oxidative polymerization, carried out amperometrically at $+700 \mathrm{mV}$ versus $\mathrm{SCE}$ for $15 \mathrm{~min}$ to produce $\mathrm{Pt}_{\mathrm{C}} / \mathrm{PPD}, \mathrm{Pt}_{\mathrm{D}} / \mathrm{PPD}$ and $\mathrm{Pt}_{\mathrm{F}} / \mathrm{PPD}$ modified electrodes. Because of the self-sealing nature of this process, longer amperometric polymerization times do not improve interference rejection of the coating. ${ }^{45}$ The relevant electrochemical properties of PPD-coated sensors based on the Pt-Ir alloy used in this study are indistinguishable from those based on pure Pt wire, ${ }^{41}$ and so the representation $\mathrm{Pt}$ is used in preference to $\mathrm{Pt}-\mathrm{Ir}$ for simplicity in modified electrode nomenclature: $\mathrm{Pt}_{\mathrm{C}} / \mathrm{PPD}$, and so on, as discussed previously. $^{2}$

Glutamate Biosensor Fabrication. Biosensors were prepared by first pre-coating the metal surface of $\mathrm{Pt}_{\mathrm{F}}$ electrodes (see Working Electrode Preparation above) with the polycation polyethyleneimine (PEI, Aldrich, $\mathrm{MW}_{\mathrm{r}} \sim 750 \mathrm{kDa}, 1 \%$ aqueous solution) by dip evaporation before enzyme deposition to boost enzyme activity, as described previously. ${ }^{31,42,46}$ The enzyme glutamate oxidase, GluOx (EC 1.4.3.11, $200 \mathrm{U} \mathrm{mL}^{-1}$, Yamasa Corp., Japan) was deposited onto the $\mathrm{Pt}_{\mathrm{F}} / \mathrm{PEI}$ by five dipevaporation steps ${ }^{45}$ and immobilized by amperometric electropolymerization, as described above for the enzyme-free sensors, to form $\mathrm{Pt}_{\mathrm{F}} / \mathrm{PEI} / \mathrm{GluOx} / \mathrm{PPD}$ biosensors.

Instrumentation and Software. Electropolymerizations and calibrations were performed in a standard three-electrode glass electrochemical cell. A saturated calomel electrode (SCE) was used as the reference electrode and a stainless steel needle served as the auxiliary electrode. Constant potential amperometry was performed at $+700 \mathrm{mV}$ versus SCE, using Chart (v5.2) software (AD Instruments Ltd., Oxford, U.K.) and a low-noise potentiostat (Biostat IV, ACM Instruments, Cumbria, U.K.).

Amperometric Calibrations. All $\mathrm{H}_{2} \mathrm{O}_{2}$ and AA calibrations on bare and PPD-modified electrodes were performed amperometrically in a standard three-electrode glass electrochemical cell containing $20 \mathrm{~mL}$ of PBS at room temperature. The applied potential for calibrations was $+700 \mathrm{mV}$ versus SCE, a common value for anodic detection of $\mathrm{H}_{2} \mathrm{O}_{2}$ in biosensor applications involving smooth $\mathrm{Pt}$ substrates. ${ }^{2,47,48}$ The $\mathrm{H}_{2} \mathrm{O}_{2}$ calibrations were carried out in the range $0-0.1 \mathrm{mM}$, prior to an AA calibration in the range $0-1 \mathrm{mM}$. The $\mathrm{H}_{2} \mathrm{O}_{2}$ calibration plots of the steadystate responses were linear at all modified surfaces, as reported previously for electrodes modified with a variety of PPD-based matrixes. ${ }^{41,49,50}$ The steady-state calibration response of AA at $\mathrm{Pt} / \mathrm{PPD}$-type electrodes is distinctively non-linear, typically forming

(45) Ryan, M. R.; Lowry, J. P.; O’Neill, R. D. Analyst 1997, 122, 1419-1424.

(46) McMahon, C. P.; Rocchitta, G.; Serra, P. A.; Kirwan, S. M.; Lowry, J. P.; O’Neill, R. D. Analyst 2006, 131, 68-72.

(47) Hamdi, N.; Wang, J. J.; Walker, E.; Maidment, N. T.; Monbouquette, H. G. J. Electroanal. Chem. 2006, 591, 33-40.

(48) Guilbault, G. G. Analytical Uses of Immobilised Enzymes; Marcel Dekker: New York, 1984.

(49) Lowry, J. P.; McAteer, K.; El Atrash, S. S.; Duff, A.; O’Neill, R. D. Anal. Chem. 1994, 66, 1754-1761.

(50) Lowry, J. P.; O’Neill, R. D. Electroanalysis 1994, 6, 369-379. a plateau at AA concentrations greater than $0.5 \mathrm{mM}$, either hyperbolically or after a relative maximum is observed (see Data Analysis below). ${ }^{40,49-51} \mathrm{The}^{\mathrm{Pt}} \mathrm{F} / \mathrm{PEI} / \mathrm{GluOx} / \mathrm{PPD}$ biosensors were calibrated with L-glutamic acid (Glu, Sigma), $\mathrm{H}_{2} \mathrm{O}_{2}$, and AA to determine the Glu slope in the linear response region (up $100 \mu \mathrm{M} \mathrm{Glu}$ ), as well as their sensitivity to $\mathrm{H}_{2} \mathrm{O}_{2}$ and AA.

Data Analysis. The transport of analytes from solution, through an insulating polymer coating on an electrode, to the underlying metal substrate where the electrochemical reactions occur, is a complex process. Two distinct transport mechanisms have been identified: movement of the analyte through "pinhole" or channel imperfections in the polymer; and diffusion of thermodynamically dissolved analyte in the polymer. ${ }^{52,53}$ Parameters involved in membrane transport include the permeant's partition and diffusion coefficients in the polymer, as well as polymer thickness. ${ }^{54,55}$ Because the thickness of the non-conducting form of PPD generated under the electrodeposition conditions used in the present work is not known accurately (estimates range from $5-30 \mathrm{~nm}^{56-60}$ ), the "true permeability" of an analyte cannot be determined in a straightforward manner. ${ }^{54}$ Instead, we have defined the "apparent permeability" of an analyte (eqs 4 and 5) as the ratio of the analyte currents recorded with the same electrode before and after deposition of the polymer. This apparent permeability is a relative, normalized measure of the analyte flux to the metal surface when the polymer coating is present, and this parameter has proved useful in comparing the properties of permselective polymers for biosensor applications. ${ }^{2,56}$

Slopes of the linear calibration plots were used to quantify the sensitivity of the bare metal to $\mathrm{H}_{2} \mathrm{O}_{2}$ and AA, and of the PPDmodified electrodes to $\mathrm{H}_{2} \mathrm{O}_{2} \cdot{ }^{50}$ Apparent analyte permeabilities have been defined (eqs 4 and 5) ${ }^{2,56}$ to quantify and compare the ability of the various non-conducting polymers to allow $\mathrm{H}_{2} \mathrm{O}_{2}$ through while inhibiting transport of AA to the underlying electrode surface, where the electro-oxidation reactions occur: ${ }^{50,55}$

$$
P(\mathrm{HP}) \%=\frac{\text { slope }(\mathrm{HP}) \text { at } \mathrm{Pt} / \mathrm{PPD}}{\text { slope }(\mathrm{HP}) \text { at bare } \mathrm{Pt}} \times 100 \%
$$

where the slopes $\left(n \mathrm{n} \mathrm{mM}^{-1}\right.$ ) for $\mathrm{H}_{2} \mathrm{O}_{2}$ (HP) were obtained from linear regression analysis of the respective calibration plots for $\mathrm{H}_{2} \mathrm{O}_{2}$ at the same Pt electrodes, before and after polymer modification.

The typical AA calibration profile, obtained by plotting the near steady-state AA responses versus AA concentration for Pt/PPD electrodes, is non-linear (see Figure 2), and a number of parameters have been defined to quantify this behavior. ${ }^{51}$ The

(51) Craig, J. D.; O’Neill, R. D. Analyst 2003, 128, 905-911.

(52) Ikeda, T.; Schmehl, R.; Denisevich, P.; Willman, K.; Murray, R. W. J. Am. Chem. Soc. 1982, 104, 2683-2691.

(53) Saveant, J. M. J. Electroanal. Chem. 1991, 302, 91-101.

(54) Pyati, R.; Murray, R. W. J. Phys. Chem. 1994, 98, 11129-11135.

(55) Centonze, D.; Malitesta, C.; Palmisano, F.; Zambonin, P. G. Electroanalysis 1994, 6, 423-429.

(56) Killoran, S. J.; O’Neill, R. D. Electrochim. Acta 2008, 53, 7303-7312.

(57) Cooper, J. M.; Pritchard, D. J. J. Mater. Sci.: Mater. Electron. 1994, 5, 111-116.

(58) Malitesta, C.; Palmisano, F.; Torsi, L.; Zambonin, P. G. Anal. Chem. 1990, 62, 2735-2740.

(59) Ohnuki, Y.; Matsuda, H.; Ohsaka, T.; Oyama, N. J. Electroanal. Chem. 1983, 158, 55-67.

(60) Myler, S.; Eaton, S.; Higson, S. P. J. Anal. Chim. Acta 1997, 357, 55-61. 

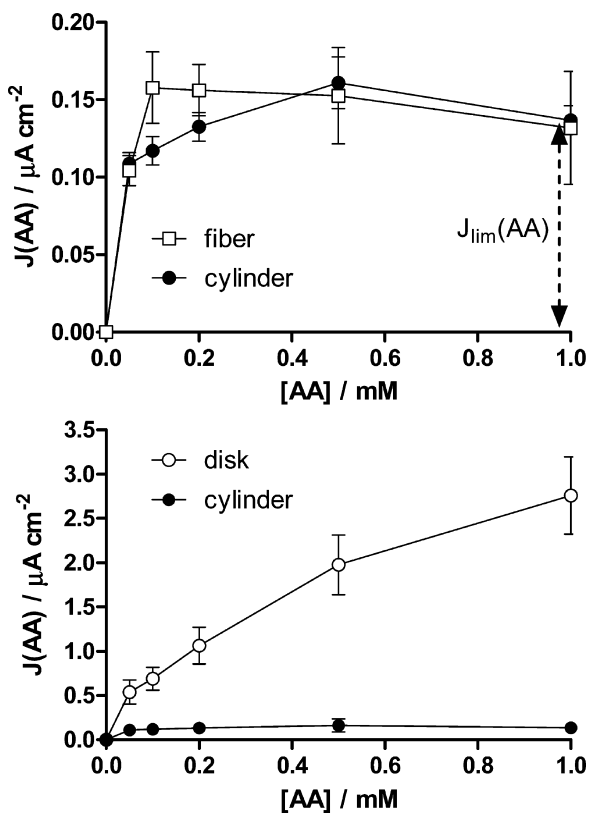

Figure 2. Samples of averaged AA calibrations for the three main designs of polymer-coated electrodes investigated here: $\mathrm{Pt}_{\mathrm{C}} / \mathrm{PPD}$ (cylinder: $125 \mu \mathrm{m}$ diameter, $1 \mathrm{~mm}$ length; $n=20$ ); $\mathrm{Pt}_{\mathrm{D}} / \mathrm{PPD}$ (disk: $125 \mu \mathrm{m}$ diameter; $n=6$ ); and $\mathrm{Pt}_{\mathrm{F}} / \mathrm{PPD}$ (fiber: $25 \mu \mathrm{m}$ diameter, $1 \mathrm{~mm}$ length; $n=6$ ). The data are expressed as current density to compare the AA response at these electrodes of different areas, calculated geometrically $\left(\mathrm{cm}^{2}\right): 4.0_{5} \times 10^{-3}, 1.2_{3} \times 10^{-4}$ and $7.9 \times 10^{-4}$, respectively.

main AA sensitivity parameter used here for PPD-modified electrodes was the limiting current at $1 \mathrm{mM}\left(I_{\lim }(\mathrm{AA})\right.$ or its current-density form $J_{\lim }(\mathrm{AA})$; see Figure 2 ) because the plateau region is the best measure of absolute interference-rejection capacity of the polymer, and because baseline brain AA levels are $\sim 0.5 \mathrm{mM},{ }^{61}$ reaching millimolar levels during a period of behavioral stimulation. ${ }^{62-64}$ The apparent permeability of AA for $\mathrm{Pt} /$ PPD was therefore defined for $1 \mathrm{mM} \mathrm{AA}$ (eq 5):

$$
P(\mathrm{AA}) \%=\frac{I_{\mathrm{AA}}(1 \mathrm{mM}) \text { at } \mathrm{Pt} / \mathrm{PPD}}{I_{\mathrm{AA}}(1 \mathrm{mM}) \text { at bare } \mathrm{Pt}} \times 100 \%
$$

where $I_{\mathrm{AA}}(1 \mathrm{mM})$ at the bare electrode was determined as the numerical value of the slope $\left(\mathrm{nA} \mathrm{mM}{ }^{-1}\right)$ of the linear calibration plots for $\mathrm{AA}$, and $I_{\mathrm{AA}}(1 \mathrm{mM})$ at Pt/PPD was the effective plateau response (nA) for $1 \mathrm{mM} A \mathrm{~A}$ at the same Pt surface following its modification by the PPD polymer (see Figure 2). Thus, both numerator and denominator in eq 5 correspond to AA responses at the same concentration, imparting a dimensionless quality to $P(\mathrm{AA}) \%$. In addition, the $P\left(\mathrm{H}_{2} \mathrm{O}_{2}\right) \%$ and $P(\mathrm{AA}) \%$ values defined by eqs 4 and 5 reflect intrinsic properties of PPD which are normalized with respect to actual electrochemical surface area, rather than geometrically calculated area. These two apparent permeability parameters were determined for individual electrodes and then averaged over populations of sensors for each design.

Polymer selectivity $(S \%)$ has been usefully defined by eq $6,{ }^{41}$ or its equivalent, ${ }^{2}$ and represents the percentage interference by

(61) Miele, M.; Fillenz, M. J. Neurosci. Meth. 1996, 70, 15-19.

(62) Boutelle, M. G.; Svensson, L.; Fillenz, M. Neuroscience 1989, 30, 11-17.

(63) O’Neill, R. D.; Fillenz, M.; Albery, W. J. J. Neurosci. Meth. 1983, 8, 263273.

(64) O’Neill, R. D.; Fillenz, M. Neurosci. Lett. 1985, 60, 331-336.
AA in $\mathrm{H}_{2} \mathrm{O}_{2}$ detection; thus the optimum value of $S \%$ defined in this way is zero for biosensor applications. The use of equimolar concentrations in this definition allows $S \%$ to be interpreted as a permselectivity for two analytes with the same $z$-value (electrons transferred per molecule), as is the case for AA and $\mathrm{H}_{2} \mathrm{O}_{2}(z=2)$ :

$$
S \%=\frac{I_{\mathrm{AA}}(1 \mathrm{mM}) \text { at } \mathrm{Pt} / \mathrm{PPD}}{I_{\mathrm{HP}}(1 \mathrm{mM}) \text { at } \mathrm{Pt} / \mathrm{PPD}} \times 100 \%
$$

where $I_{\mathrm{AA}}(1 \mathrm{mM})$ at Pt/PPD was the same as for eq 5 , and $I_{\mathrm{HP}}(1 \mathrm{mM})$ was determined as the numerical value of the slope $(\mathrm{nA} \mathrm{mM})^{-1}$ ) of the linear calibration plots for $\mathrm{H}_{2} \mathrm{O}_{2}$ at Pt/PPD.

Values of parameters are presented as mean \pm standard error (SEM), with $n=$ number of electrodes. Differences observed in parameters measured under different conditions were analyzed statistically using Student's two-tailed unpaired $t$ tests (GraphPad Prism 4, San Diego, CA), with values of $p<0.05$ considered to indicate statistical significance of the difference.

\section{RESULTS AND DISCUSSION}

Experimental Design and Calibrations. An important goal in recent biosensor research is the fabrication of amperometric microsensors suitable for tissue implantation in vivo, ${ }^{17,65-69}$ especially for brain neurochemical monitoring. ${ }^{2,29,39,70,71}$ In this context, size and geometry are critical as both determine the extent of tissue damage caused by insertion of the probe, ${ }^{72-74}$ as well as the spatial resolution of the tissue sampled. These implantable biosensors must also be able to reject electrochemical interference by reducing agents present in the tissue, and a common strategy is the incorporation of a permselective membrane on the biosensor surface, such as electropolymerized PPD. ${ }^{43,75-80}$ This polymer is unusual ${ }^{81}$ in that it displays very high permeability to the biosensor signal transduction molecule $\left(\mathrm{H}_{2} \mathrm{O}_{2}\right.$,

(65) Ahmad, F.; Yusof, A. P. M.; Bainbridge, M.; Ab Ghani, S. Biosens. Bioelectron. 2008, 23, 1862-1868.

(66) Burmeister, J. J.; Pomerleau, F.; Huettl, P.; Gash, C. R.; Wemer, C. E.; Bruno, J. P.; Gerhardt, G. A. Biosens. Bioelectron. 2008, 23, 1382-1389.

(67) Masson, J. F.; Kranz, C.; Mizaikoff, B.; Gauda, E. B. Anal. Chem. 2008, 80, 3991-3998.

(68) Wassum, K. M.; Tolosa, V. M.; Wang, J. J.; Walker, E.; Monbouquette, H. G.; Maidment, N. T. Sensors 2008, 8, 5023-5036.

(69) Kulagina, N. V.; Michael, A. C. Anal. Chem. 2003, 75, 4875-4881.

(70) van der Zeyden, M.; Denziel, W. H.; Rea, K.; Cremers, T. I.; Westerink, B. H. Pharmacol., Biochem. Behav. 2008, 90, 135-147.

(71) Wilson, G. S.; Johnson, M. A. Chem. Rev. 2008, 108, 2462-2481.

(72) Fumero, B.; Guadalupe, T.; Valladares, F.; Mora, F.; O’Neill, R. D.; Mas, M.; Gonzalez-Mora, J. L. J. Neurochem. 1994, 63, 1407-1415.

(73) Duff, A.; O’Neill, R. D. J. Neurochem. 1994, 62, 1496-1502.

(74) Peters, J. L.; Miner, L. H.; Michael, A. C.; Sesack, S. R. J. Neurosci. Meth. 2004, 137, 9-23.

(75) Fu, Y. C.; Chen, C.; Xie, Q. J.; Xu, X. H.; Zou, C.; Zhou, Q. M.; Tan, L.; Tang, H.; Zhang, Y. Y.; Yao, S. Z. Anal. Chem. 2008, 80, 5829-5838.

(76) O’Brien, K. B.; Killoran, S. J.; O’Neill, R. D.; Lowry, J. P. Biosens. Bioelectron. 2007, 22, 2994-3000.

(77) Reyes-De-Corcuera, J. I.; Cavalieri, R. P.; Powers, J. R.; Tang, J. M.; Kang, D. H. J. Agr. Food Chem. 2005, 53, 8866-8873.

(78) Dai, Y. Q.; Shiu, K. K. Electroanalysis 2004, 16, 1806-1813.

(79) Yao, T.; Yano, T.; Nanjyo, Y.; Nishino, H. Anal. Sci. 2003, 19, 61-65.

(80) Bartlett, P. N.; Birkin, P. R.; Wang, J. H.; Palmisano, F.; Debenedetto, G. Anal. Chem. 1998, 70, 3685-3694.

(81) Murphy, L. J. Anal. Chem. 1998, 70, 2928-2935. 
see reactions 2 and 3) while being remarkably effective at blocking a variety of interference molecules, ${ }^{41,51,56,82-84}$ with, for example, $P(\mathrm{AA}) \%$ values (eq 5$)$ of less than $0.1 \%$ reported recently for $\mathrm{Pt}_{\mathrm{C}} / \mathrm{PPD}$ electrodes. ${ }^{82}$ Implanted $\mathrm{Pt}_{\mathrm{C}}$-based biosensors, however, sample the ECF around a relatively large population of cells, and smaller designs are needed both to reduce tissue damage (by reducing sensor diameter), and to study small brain regions or layers of cells within regions, for example, by using disk sensors. In this study, we fabricated Pt/PPD electrodes of different sizes and geometries to determine their sensitivity to $\mathrm{H}_{2} \mathrm{O}_{2}$ and to the archetypal interference species, AA. Calibration of the same electrodes for these two analytes before and after PPD deposition allowed calculation of the apparent permeabilities for $\mathrm{H}_{2} \mathrm{O}_{2}$ and $\mathrm{AA}$ (eqs 4 and 5). These parameters were used to determine whether the excellent selectivity properties, reported for the $\mathrm{Pt}_{\mathrm{C}} / \mathrm{PPD}$ design ${ }^{56,82}$ scaled down for smaller sensors.

Ascorbate Calibrations at Bare Electrodes. The response of bare $125 \mu \mathrm{m}$ diameter Pt-Ir electrodes to AA was linear in the range tested $(0-1 \mathrm{mM})$ for both $\mathrm{Pt}_{\mathrm{C}}\left(140 \pm 6 \mu \mathrm{A} \mathrm{cm}^{-2} \mathrm{mM}^{-1}, n\right.$ $\left.=60, R^{2}=0.9995\right)$ and $\mathrm{Pt}_{\mathrm{D}}\left(145 \pm 8 \mu \mathrm{A} \mathrm{cm}^{-2} \mathrm{mM}^{-1}, n=69\right.$, $\left.R^{2}=0.998\right)$ with no statistical difference observed between these averaged individual slopes for the two geometries $(p>$ 0.66). These new determinations for $\mathrm{Pt}_{\mathrm{C}}$ are in line with other populations determined previously. ${ }^{41,51}$ The similarity between the AA slopes for $\mathrm{Pt}_{\mathrm{C}}$ and $\mathrm{Pt}_{\mathrm{D}}$ electrodes demonstrates that neither subtle differences in the radial diffusion profiles for these two geometries nor the different condition of the metal surface (pristine cut for $\mathrm{Pt}_{\mathrm{D}}$ vs the Teflon-stripped origin of the $\mathrm{Pt}_{\mathrm{C}}$ cylinder; see Figure 1$)^{44,85}$ significantly affected $\mathrm{AA}$ sensitivity for the bare electrodes under the recording conditions used.

A different approach was taken with the linear AA calibration slopes for $\mathrm{Pt}_{\mathrm{F}}$ electrodes. Because it was difficult to determine exactly where the thin glass seal ended and the bare metal started (Figure 1), the length of the exposed fibers was ascertained electrochemically. Previous work has shown that the AA sensitivity is the same at pure Pt and the Pt-Ir alloy used here, measured both cyclic voltammetrically and amperometrically (Pt: $147 \pm 27 \mu \mathrm{A} \mathrm{cm}^{-2} \mathrm{mM}^{-1}, n=10$; Pt-Ir: $148 \pm 7 \mu \mathrm{A} \mathrm{cm}^{-2}$ $\left.\mathrm{mM}^{-1}, n=20 ; p>0.96\right) .{ }^{41}$ Benchmark AA current-density slope (see above) was therefore combined with individual calibration slopes to calculate the effective electrochemical length of each $\mathrm{Pt}_{\mathrm{F}}$ electrode. A plot of this electrochemical length versus the length measured, using an optical microscope, was linear with a slope not significantly different from unity ( $\left.0.97 \pm 0.02, R^{2}=0.9994, n=45\right)$ indicating that the optical method was accurate enough for the present purposes, except for very short fibers $(<0.2 \mathrm{~mm})$.

Ascorbate Calibrations at PPD-Modified Electrodes. Averaged steady-state $\mathrm{AA}$ calibrations for sample populations of $\mathrm{Pt}_{\mathrm{C}} /$ $\mathrm{PPD}, \mathrm{Pt}_{\mathrm{D}} / \mathrm{PPD}$, and $\mathrm{Pt}_{\mathrm{F}} / \mathrm{PPD}$ sensors (see Figure 1 ) are shown

(82) Rothwell, S. A.; Killoran, S. J.; Neville, E. M.; Crotty, A. M.; O’Neill, R. D. Electrochem. Commun. 2008, 10, 1078-1081.

(83) Schuvailo, O. M.; Soldatkin, O. O.; Lefebvre, A.; Cespuglio, R.; Soldatkin, A. P. Anal. Chim. Acta 2006, 573, 110-116.

(84) Dai, Y. Q.; Zhou, D. M.; Shiu, K. K. Electrochim. Acta 2006, 52, 297303.

(85) McMahon, C. P.; O'Neill, R. D. Anal. Chem. 2005, 77, 1196-1199. in Figure 2. Although the PPD electrodeposited in this study did not have the trapped globular proteins of previous work, ${ }^{40,51,86}$ the same distinctive behavior was evident, principally a flat plateau in response for the major part of the concentration range up to 1 $\mathrm{mM}$. This shape has been explained in terms of saturation of the PPD with AA and its oxidation products, leading to a "selfblocking" phenomenon and an AA response which is largely concentration independent. ${ }^{50,51,56}$ The plateau feature, which is analytically relevant because AA levels in brain ECF can vary spontaneously over this range, ${ }^{61,87,88}$ was observed for $1 \mathrm{~mm}$ cylinder configurations of $\mathrm{Pt}_{\mathrm{C}}$ and $\mathrm{Pt}_{\mathrm{F}}$ (Figure 2, top), but was not as clear-cut for $\mathrm{Pt}_{\mathrm{D}} / \mathrm{PPD}$ disk electrodes (Figure 2, bottom). More importantly, the $J_{\lim }(\mathrm{AA})$ value for $\mathrm{Pt}_{\mathrm{D}} / \mathrm{PPD}(2.8 \pm 0.4 \mu \mathrm{A}$ $\left.\mathrm{cm}^{-2}, n=6\right)$ was much greater than for $\mathrm{Pt}_{\mathrm{C}} / \mathrm{PPD}(0.14 \pm 0.01$ $\left.\mu \mathrm{A} \mathrm{cm}{ }^{-2}, n=20, p<0.0001\right)$, as observed for a similar comparison of Pt-Ir-coated PPD containing globular protein. In that study, ${ }^{40}$ it was suggested that electrode size played a role in the divergence of the $\mathrm{Pt}_{\mathrm{C}} / \mathrm{PPD}$ and $\mathrm{Pt}_{\mathrm{D}} / \mathrm{PPD}$ behavior. The finding here, however, that this sample of $\mathrm{Pt}_{\mathrm{C}} / \mathrm{PPD}$ sensors $\left(4.0_{5} \times 10^{-3} \mathrm{~cm}^{2}\right)$ behaved in a very similar way (see Figure 2, top) to $1 \mathrm{~mm}$ long $\mathrm{Pt}_{\mathrm{F}} / \mathrm{PPD}$ electrodes $\left(7.9 \times 10^{-4} \mathrm{~cm}^{2}\right)$ indicates that this explanation is inadequate. Neither can minor Teflon damage at the cut $\mathrm{Pt}_{\mathrm{D}}$ surface, nor geometry per se, hold the key to understanding this difference (e.g., more efficient hemispherical AA diffusion to $\mathrm{Pt}_{\mathrm{D}}$ versus cylindrical diffusion to $\mathrm{Pt}_{\mathrm{C}}$ ) because these factors were too small to affect $\mathrm{AA}$ responses at even the bare electrodes on the time scale of these constant potential amperometric measurements (see Ascorbate Calibrations at Bare Electrodes).

P(AA)\% Analysis for PPD-Modified Electrodes. To ascertain the cause of the different AA responses shown in Figure 2, $P(\mathrm{AA}) \%$ was calculated, using calibration $I_{\lim }(\mathrm{AA})$ values (eq 5), for $\mathrm{Pt}_{\mathrm{C}} / \mathrm{PPD}$ and $\mathrm{Pt}_{\mathrm{D}} / \mathrm{PPD}$ of different diameters (50 and 125 $\mu \mathrm{m})$ and $1 \mathrm{~mm}$ long $25 \mu \mathrm{m}$ diameter $\mathrm{Pt}_{\mathrm{F}} / \mathrm{PPD}$ electrodes. These were combined with $P(\mathrm{AA}) \%$ values calculated from literature $I_{\lim }(\mathrm{AA})$ values for $250 \mu \mathrm{m}$ Pt wire disks ${ }^{50}$ and $1.6 \mathrm{~mm}$ diameter Pt disks ${ }^{89}$ to examine the trends in $P(\mathrm{AA}) \%$ over an extended range of electrode size for cylinder and disk geometries.

Table 1 shows the mean apparent AA permeability, $P(\mathrm{AA}) \%$, values for seven electrode sizes (3 orders of magnitude range), together with the corresponding geometrically calculated electrode area, edge length, and edge density (the ratio of edge length to area). Here "edge" refers to the interface between the metal surface and the insulation (Teflon or glass; see Figure 1). Contrary to the expectation that this intensive property of the polymer, that is, $P(\mathrm{AA}) \%$, should be similar for all cases where PPD was electrodeposited on Pt under the same conditions, there was a 50-fold span in $P(\mathrm{AA}) \%$ values across the range of Pt/PPD sizes studied here. Because a number of area-normalized electrochemical signal parameters remain dependent on electrode area, ${ }^{90,91}$ $P(\mathrm{AA}) \%$ was plotted versus $\mathrm{Pt}$ area to determine whether a straightforward relationship existed between these two param-

(86) McAteer, K.; O’Neill, R. D. Analyst 1996, 121, 773-777.

(87) Fillenz, M.; O’Neill, R. D. J. Physiol. (London) 1986, 374, 91-101.

(88) Zhang, M. N.; Liu, K.; Xiang, L.; Lin, Y. Q.; Su, L.; Mao, L. Q. Anal. Chem. 2007, 79, 6559-6565.

(89) O’Neill, R. D.; Chang, S. C.; Lowry, J. P.; McNeil, C. J. Biosens. Bioelectron. 2004, 19, 1521-1528.

(90) Schrock, D. S.; Baur, J. E. Anal. Chem. 2007, 79, 7053-7061.

(91) Forster, R. J. Chem. Soc. Rev. 1994, 23, 289-297. 


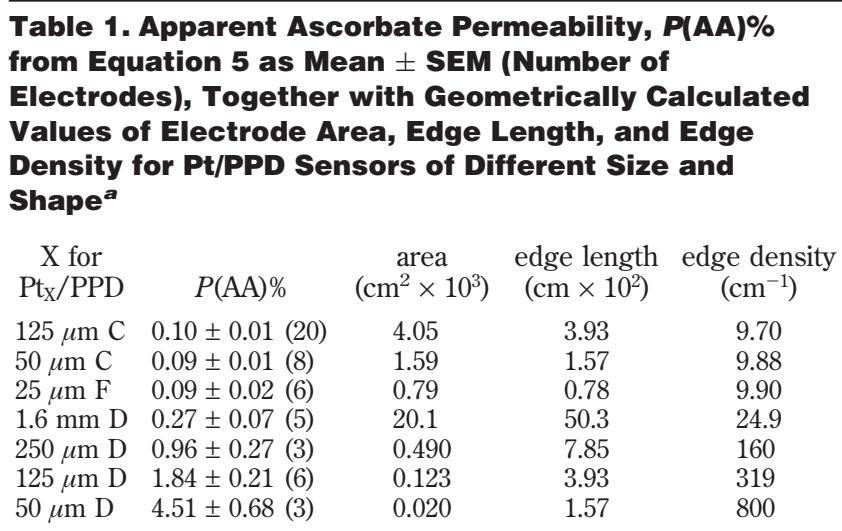

${ }^{a} \mathrm{X}$, column 1 : $\mathrm{C}$ is wire cylinder, $\mathrm{D}$ is wire disk, and $\mathrm{F}$ is fiber cylinder; see Figure 1 . All cylinders $(\mathrm{C}$ and $\mathrm{F})$ in this data set were 1 $\mathrm{mm}$ in length; electrode diameters are given in column 1.
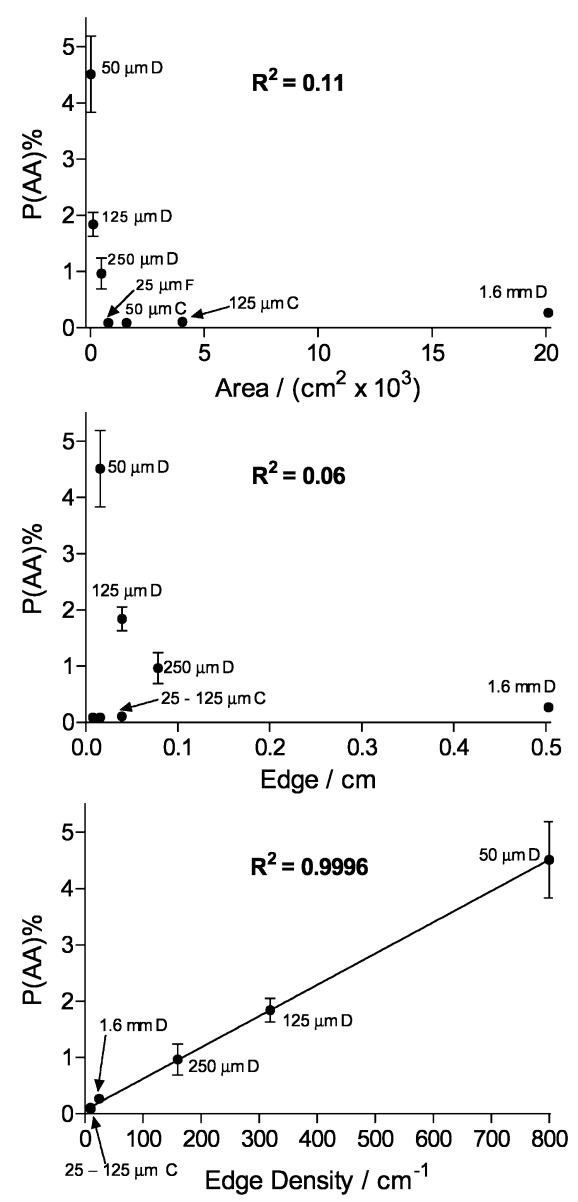

Figure 3. Plots of averaged values of $P(\mathrm{AA}) \%$ (eq 5 ) for seven variations of Pt electrode geometry and size versus working electrode area (top), edge length (middle), and edge density (bottom). $R^{2}$ values were calculated using linear regression. For the bottom plot, the slope $(0.55 \pm 0.01 \% \cdot \mathrm{m})$ and $P(\mathrm{AA}) \%$ intercept $(0.06 \pm 0.02 \%)$ were significant. Where the $\mathrm{Pt}_{\mathrm{F}}$ fiber data overlap with wire $\mathrm{Pt}_{\mathrm{C}}$ values (middle and bottom graphs), the labels are grouped as " $25-125 \mu \mathrm{m}$ C" for clarity; see Table 1 for all $P(A A) \%$ data and geometric parameter values.

eters. Figure 3 (top) shows that there was no simple linear or non-linear pattern in this plot (e.g., linear regression $R^{2}=0.11$ ), with the smallest electrodes displaying both the lowest and highest values of $P(\mathrm{AA}) \%$ observed. Some electrochemical phenomena are also known to be affected by the edge component of bare electrodes; ${ }^{92,93} P(\mathrm{AA}) \%$ was therefore plotted versus Pt edge length. Figure 3 (middle) again shows that there was no simple pattern in this plot (linear regression $R^{2}=0.06$ ), with the smallest edge being associated with both the lowest and highest values of $P(\mathrm{AA}) \%$ observed.

The value of $P(\mathrm{AA}) \%$ for any electrode is an average of the AA permeability over the entire PPD deposit. The PPD coating can be thought of as having two main components: a bulk region far from any edge $\left(\mathrm{PPD}_{\text {bulk }}\right)$; and PPD deposited near the insulating glass or Teflon (see Figure $1 ; \mathrm{PPD}_{\text {edge}}$ ) which might not offer the same barrier to AA penetration. Thus, the apparent AA permeability for a given sensor is an average of AA permeability for $\mathrm{PPD}_{\text {bulk }}$ and $\mathrm{PPD}_{\text {edge }}$, each weighted according to the relative amounts of these two PPD components. For example, the 125 $\mu \mathrm{m}$ diameter $\mathrm{Pt}_{\mathrm{D}}$ and $\mathrm{Pt}_{\mathrm{C}}$ designs both have the same edge length (Figure 1 and Table 1), and therefore similar amounts of $\mathrm{PPD}_{\text {edge, }}$, but very different amounts of $\mathrm{PPD}_{\text {bulk. }}$. The $P(\mathrm{AA}) \%$ value for $\mathrm{Pt}_{\mathrm{C}} / \mathrm{PPD}$ would therefore be dominated by the ability of $\mathrm{AA}$ to permeate $\mathrm{PPD}_{\text {bulk. }}$. Following this reasoning, we define here the "edge density" as the ratio of edge length to electrode area, to quantify the relative weighting of these two regions of the PPD coating.

The plot of $P(\mathrm{AA}) \%$ versus edge density (Figure 3, bottom) was linear $\left(R^{2}=0.9996\right)$ over the entire range of sensor size studied. Thus, when the edge density was high (e.g., small disk electrodes) the overall $P(\mathrm{AA}) \%$ was high because $\mathrm{PPD}_{\text {edge }}$ predominates, and this appears to offer a less effective barrier to AA penetration. Conversely, when the edge density was low (e.g., large disk and $1 \mathrm{~mm}$ long cylinder electrodes) the overall $P(\mathrm{AA}) \%$ was low (excellent $\mathrm{AA}$ blocking) because $\mathrm{PPD}_{\text {bulk }}$ predominates. These arguments are consistent with $P(\mathrm{AA}) \%_{\text {edge }}$ $>P(\mathrm{AA}) \%_{\text {bulk }}$, and estimates of these two permeability components can be obtained from the slope $(0.55 \pm 0.01 \% \cdot \mathrm{m})$ and $y$-intercept (zero edge density: $0.06 \pm 0.02 \%$ ) of the linear regression analysis, respectively (Figure 3, bottom). Most importantly, this analysis indicates that the limiting permeability of bulk PPD (no edges present) was $0.06 \pm 0.02 \%$, that is, PPD deposited under these conditions is capable of blocking $99.94 \%$ of the AA flux to the metal surface. See below for an independent determination of these two PPD components for $\mathrm{Pt}_{\mathrm{F}} / \mathrm{PPD}$ sensors.

$P(\mathrm{AA}) \%, \boldsymbol{P}\left(\mathrm{H}_{2} \mathrm{O}_{2}\right) \%$, and $\mathrm{S} \%$ Analyses for $\mathrm{Pt}_{\mathrm{F}} / \mathrm{PPD}$ Electrodes. Given the conclusions from Figure 3 above, the permeability and selectivity parameters for the fiber $\mathrm{Pt}_{\mathrm{F}} / \mathrm{PPD}$ electrodes were analyzed only in terms of edge density. A plot of $P(\mathrm{AA}) \%$ values for 36 individual $\mathrm{Pt}_{\mathrm{F}} / \mathrm{PPD}$ electrodes of different lengths (0.06-2.0 mm, determined electrochemically; see Ascorbate Calibrations at Bare Electrodes, above) is shown in Figure 4. This large population of individual electrodes revealed that the edge-related increase in $P(\mathrm{AA}) \%$ was not perceptible for small edge densities (below $50 \mathrm{~cm}^{-1}$ ), corresponding to fiber lengths of $>0.2 \mathrm{~mm}$. For shorter fibers, $P(\mathrm{AA}) \%$ increased with a slope of $0.47 \pm 0.11 \% \cdot \mathrm{m}\left(R^{2}=0.68, p<0.004, n=12\right)$, which was not significantly different from the slope calculated from the

(92) Cope, D. K. J. Electroanal. Chem. 1997, 439, 7-27.

(93) Ju, H. X.; Chen, H. Y.; Gao, H. J. Electroanal. Chem. 1993, 361, 251-256. 


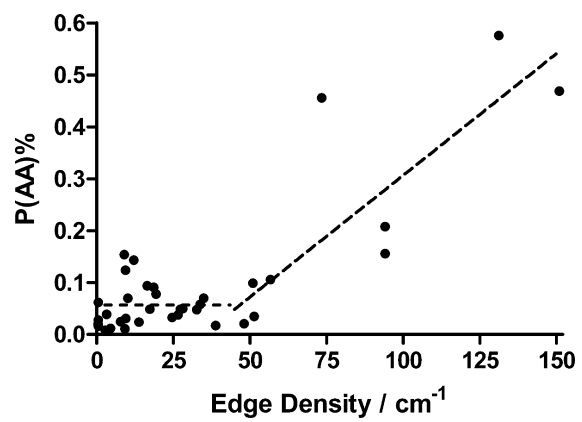

Figure 4. Plot of $P(\mathrm{AA}) \%$ values (eq 5 ) for 36 individual $\mathrm{Pt}_{\mathrm{F}} / \mathrm{PPD}$ electrodes of different lengths versus edge density. This large population revealed that the edge-related increase in $P(\mathrm{AA}) \%$ (see Figure 3, bottom) was not perceptible for small edge densities (below $50 \mathrm{~cm}^{-1}$ ) corresponding to fiber lengths of $>0.2 \mathrm{~mm}$. For shorter fibers, $P(\mathrm{AA}) \%$ increased with a slope of $0.47 \pm 0.11 \% \cdot \mathrm{m}\left(\mathrm{R}^{2}=\right.$ $0.68, p<0.004, n=12$ ). The average $P(\mathrm{AA}) \%$ value for longer fibers $(0.2-2.0 \mathrm{~mm})$ was $0.06 \pm 0.01 \%, n=30$.

principally wire-based averaged data in Figure 3. The coefficient of variance was significantly higher for the slope obtained from the plot of $P(\mathrm{AA}) \%$ for fiber electrodes (Figure 4 ) compared with that in Figure 3. This is not surprising, both because the individual fiber $P(\mathrm{AA}) \%$ values (affecting $y$-variance) were used in Figure 4 in contrast to averaged values for the different designs in Figure 3 and because the geometry of the glass edge (affecting $x$-variance) in $\mathrm{Pt}_{\mathrm{F}} / \mathrm{PPD}$ electrodes is not expected to be as well-defined as that of the Teflon edge of the wire-based sensors that predominate in Figure 3. The finding, however, that the two slopes (Figures 3 and 4) were indistinguishable supports the linear regression analysis of the small subpopulation of short fibers in Figure 4. For longer fibers $(0.2-2.0 \mathrm{~mm}), P(\mathrm{AA}) \%$ was very reproducible $(0.06 \pm 0.01 \%, n=30)$, the same value as for the limiting intercept of the plot of non-fiber data in Figure 3. Thus, the intrinsic AA permeability for the PPD polymer deposited on $\mathrm{Pt}$ macro-disks, $\mathrm{Pt}_{\mathrm{C}}, \mathrm{Pt}_{\mathrm{D}}$, and $\mathrm{Pt}_{\mathrm{F}}$ electrodes under these conditions is $0.06 \pm 0.01 \%$, which represents an excellent blocking of $99.94 \%$ of the AA interference for biosensor applications. Higher $P(\mathrm{AA}) \%$ values (poorer blocking) were observed for sensor designs involving a significant edge density, especially small disk electrodes, apparently because of easier access by AA through PPD deposited near the electrode insulation.

Figure 5 shows plots of $P\left(\mathrm{H}_{2} \mathrm{O}_{2}\right)$ \% (eq 4) and $S \%$ (eq 6) values for 30 individual $\mathrm{Pt}_{\mathrm{F}} / \mathrm{PPD}$ electrodes of different lengths $(0.06-2.0 \mathrm{~mm})$ versus edge density. There was no statistically significant trend in the $P\left(\mathrm{H}_{2} \mathrm{O}_{2}\right)$ \% data over the entire range of fiber lengths (linear regression $R^{2}=0.03$ ). This is in line with expectation, because the high $\mathrm{H}_{2} \mathrm{O}_{2}$ permeability in $\mathrm{PPD}$ is one of its outstanding qualities which makes this polymer (both ortho and meta forms ${ }^{56,83,94}$ the permselective membrane of choice in many first-generation biosensor designs. ${ }^{17,78,81,85}$ Thus, the compromised structure of PPD deposited at the insulation edge, indicated by the analysis for $P(\mathrm{AA}) \%$ above, would not be anticipated to impact on $P\left(\mathrm{H}_{2} \mathrm{O}_{2}\right)$ \% values already close to those for the bare metal. We await the commissioning of a scanning electrochemical microscope to probe the structure of the

(94) Netchiporouk, L. I.; Shram, N. F.; Jaffrezic-Renault, N.; Martelet, C.; Cespuglio, R. Anal. Chem. 1996, 68, 4358-4364.
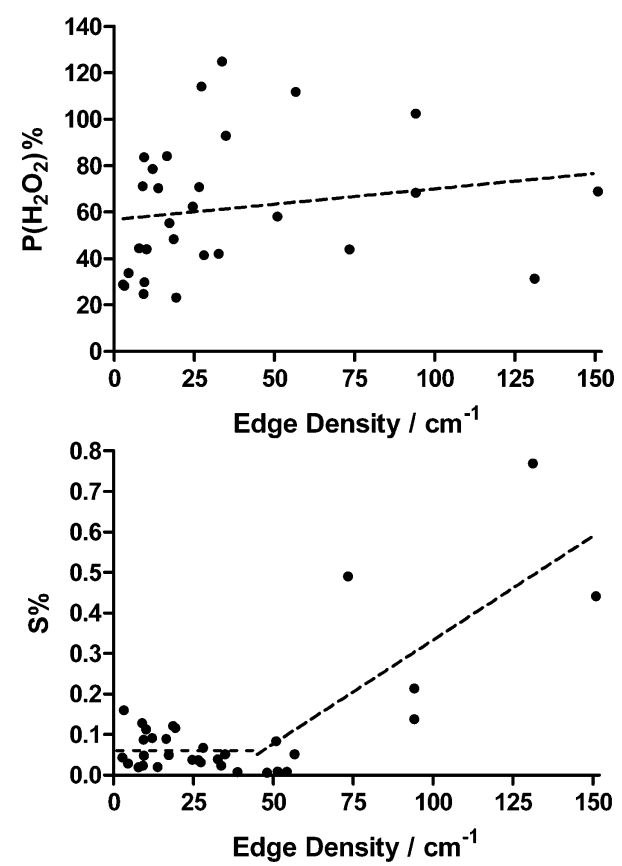

Figure 5. Plots of $P\left(\mathrm{H}_{2} \mathrm{O}_{2}\right) \%$ (eq 4, top) and $S \%$ (eq 6, bottom) values for 30 individual $\mathrm{Pt}_{\mathrm{F}} / \mathrm{PPD}$ electrodes of different lengths versus edge density. There was no statistically significant trend in the $P\left(\mathrm{H}_{2} \mathrm{O}_{2}\right) \%$ data (linear regression $R^{2}=0.03$ ). The edge-related increase in $S \%$, as expected from the $P(A A) \%$ profile (Figure 4), was again detected for edge densities above $50 \mathrm{~cm}^{-1}$ (slope of $0.51 \pm$ $0.11 \% \cdot \mathrm{m}, R^{2}=0.65, p<0.001, n=12$ ), corresponding to fiber lengths of $<0.2 \mathrm{~mm}$. For longer fibers $(0.2-2.0 \mathrm{~mm}), S \%$ was very reproducible with an average value of $0.057 \pm 0.008 \%, n=24$.

PPD-edge interface; scanning electron microscopy, which has revealed interesting aspects of PPD structure in the past, ${ }^{50,56,95}$ tends to "burn" organic polymer deposits at the high magnifications needed to study this level of detail.

The edge-related increase in $S \%$, expected from the $P(\mathrm{AA}) \%$ profile (Figure 4), was indeed detected for edge densities above $50 \mathrm{~cm}^{-1}$ (slope of $0.51 \pm 0.11 \% \cdot \mathrm{m}, R^{2}=0.65, p<0.001, n=$ 12), corresponding to fiber lengths of $<0.2 \mathrm{~mm}$. For longer fibers $(0.2-2.0 \mathrm{~mm}), S \%$ was very reproducible with an average value of $0.057 \pm 0.008 \%, n=24$, representing a $0.06 \%$ interference level by $\mathrm{AA}$ in $\mathrm{H}_{2} \mathrm{O}_{2}$ detection for equimolar concentrations.

Biosensor Performance of $\mathrm{Pt}_{\mathrm{F}} / \mathrm{PEI} / \mathrm{GluOx} / \mathrm{PPD}$ Electrodes. The excellent AA rejection properties $(P(\mathrm{AA}) \%, 0.06 \pm$ $0.01 \%)$, narrow cross-sectional area $\left(\sim 5 \times 10^{-6} \mathrm{~cm}^{2}\right)$, and small overall area of the $>0.2 \mathrm{~mm}$ long $\mathrm{Pt}_{\mathrm{F}} / \mathrm{PPD}$ configuration make this an attractive candidate for the design of an implantable biosensor for brain Glu. Pt $/ \mathrm{PEI} / \mathrm{GluOx} / \mathrm{PPD}$ biosensors, incorporating the enzyme GluOx and sensitivity-boosting polycation PEI, ${ }^{31,42,46,96}$ were therefore fabricated and calibrated in vitro for $\mathrm{Glu}, \mathrm{H}_{2} \mathrm{O}_{2}$, and AA. The sensitivity to Glu in the linear response region of the Michaelis-Menten calibration curve was high ( $\left.62 \pm 8 \mu \mathrm{A} \mathrm{cm}^{-2} \mathrm{mM}^{-1}, n=14\right)$, representing $24 \pm$ $4 \%$ of the sensitivity of the same biosensors in $\mathrm{H}_{2} \mathrm{O}_{2}$ calibrations performed under the same quiescent conditions, and reflecting efficient enzyme kinetics in these ultrathin insulating PPD coatings $\left.\left(<30 \mathrm{~nm}^{56-60}\right)\right)^{2,42,43}$ The values of $P\left(\mathrm{H}_{2} \mathrm{O}_{2}\right) \%(119 \pm$

(95) Wang, J.; Chen, Q.; Renschler, C. L.; White, C. Anal. Chem. 1994, 66, 1988-1992.

(96) Varma, S.; Yigzaw, Y.; Gorton, L. Anal. Chim. Acta 2006, 556, 319-325. 
$14 \%, n=14)$ and $P(\mathrm{AA}) \%(0.20 \pm 0.04 \%, n=14)$ indicate that the dip-evaporation deposition of both PEI and GluOx on the bare $\mathrm{Pt}_{\mathrm{F}}$ before PPD electrosynthesis only marginally affected the ability of the composite polymer matrix to reject AA interference or to enable efficient $\mathrm{H}_{2} \mathrm{O}_{2}$ transport to the metal surface. Not surprisingly, as a result of incorporating these two macromolecular species into the PPD matrix, its permeability increased, but by only a factor of 2 for both parameters (see Figures 4 and 5), minimizing the effects on selectivity.

\section{CONCLUSIONS}

Data and analysis of apparent AA permeability for Pt/PPD sensors of different sizes and shapes indicate that the PPD deposited near the electrode insulation (Teflon or glass) is not as effective as the bulk surface PPD for blocking AA access to the Pt surface, limiting its use as a permselective coating in certain geometries of first-generation biosensors. This effect was particularly marked at small disk electrodes, which have a high edge density. To some extent, the choice of a particular size and geometry in designing implantable biosensors will depend on the selectivity needed, that is, the ratio of target analyte concentration to interference levels, as well as the size and shape of the tissue (e.g., brain region) of interest. For biosensors designed to monitor concentration dynamics of neurotransmitters present in the ECF at low micromolar levels, such as Glu, ${ }^{26,31,97,98}$ short Pt fiber cylinder electrodes ( $\mathrm{Pt}_{\mathrm{F}}$, but $\geq 0.2 \mathrm{~mm}$ long), of the range studied here, appear to offer the best balance of characteristics: minimal tissue damage; small overall area, giving good spatial resolution; and a negligible edge effect providing excellent interference rejection. A sample biosensor design $\left(\mathrm{Pt}_{\mathrm{F}} / \mathrm{PEI} / \mathrm{GluOx} / \mathrm{PPD}\right)$ based on this format behaved well in vitro in terms of Glu sensitivity and AA blocking.

Full in vivo characterization of similar designs is being planned to determine whether these properties survive the implantation process and tissue environment. The demonstrated success of

(97) Oldenziel, W. H.; Dijkstra, G.; Cremers, T. I. F. H.; Westerink, B. H. C. Brain Res. 2006, 1118, 34-42.

(98) Kulagina, N. V.; Shankar, L.; Michael, A. C. Anal. Chem. 1999, 71, 50935100 .
PPD-based biosensors for in vivo brain glucose and lactate monitoring during behavior is a promising indication for the $\mathrm{Pt}_{\mathrm{F}} /$ PPD devices, ${ }^{2,83,94,99-101}$ although the significantly lower concentration of brain ECF Glu relative to glucose means that the selectivity and stability will need to be outstanding. These properties, which have been achieved recently for other designs, including Nafion-coated microelectrode arrays, ${ }^{21,26,83,102}$ can only be determined reliably in vivo, which is another stage of our ongoing program to develop simple wire-based PPD-modified implantable microbiosensors for brain Glu.

Scanning electrochemical microscopy studies are also planned to probe the structure of the PPD-edge interface. Further investigations will include microband arrays to determine whether similar edge effects are observed at this class of electrode, ${ }^{103}$ a format finding increasing use in the design of implantable biosensors. ${ }^{104,105}$

\section{ACKNOWLEDGMENT}

This work was funded in part by the Irish Research Council for Science, Engineering and Technology (IRCSET), and by Science Foundation Ireland (03/IN3/B376 and 03/IN3/B376s). We thank Dr. Kusakabe of Yamasa Corp., Japan for a generous gift of glutamate oxidase.

Received for review January 22, 2009. Accepted March 24, 2009.

\section{AC900162C}

(99) Dixon, B. M.; Lowry, J. P.; O'Neill, R. D. J. Neurosci. Meth. 2002, 119, 135-142.

(100) Lowry, J. P.; Miele, M.; O’Neill, R. D.; Boutelle, M. G.; Fillenz, M. J. Neurosci. Meth. 1998, 79, 65-74.

(101) Lowry, J. P.; O’Neill, R. D.; Boutelle, M. G.; Fillenz, M. J. Neurochem. 1998, 70, 391-396.

(102) Oldenziel, W. H.; Dijkstra, G.; Cremers, T. I. F. H.; Westerink, B. H. C. Anal. Chem. 2006, 78, 3366-3378.

(103) Porat, Z.; Crooker, J. C.; Zhang, Y. N.; Lemest, Y.; Murray, R. W. Anal. Chem. 1997, 69, 5073-5081.

(104) Thomas, T. C.; Grandy, D. K.; Gerhardt, G. A.; Glaser, P. E. A. Neuropsychopharmacology 2009, 34, 436-445.

(105) Dash, M. B.; Douglas, C. L.; Vyazovskiy, V. V.; Cirelli, C.; Tononi, G. J. Neurosci. 2009, 29, 580-589. 